\title{
Modelling the impact of climate change on rangeland forage production using a generalized regression neural network: a case study in Isfahan Province, Central Iran
}

\author{
Zahra JABERALANSAR*, Mostafa TARKESH, Mehdi BASSIRI, Saeid POURMANAFI \\ Department of Natural Resources, Isfahan University of Technology, Isfahan 84156-83111, Iran
}

\begin{abstract}
Monitoring of rangeland forage production at specified spatial and temporal scales is necessary for grazing management and also for implementation of rehabilitation projects in rangelands. This study focused on the capability of a generalized regression neural network (GRNN) model combined with GIS techniques to explore the impact of climate change on rangeland forage production. Specifically, a dataset of 115 monitored records of forage production were collected from 16 rangeland sites during the period 1998-2007 in Isfahan Province, Central Iran. Neural network models were designed using the monitored forage production values and available environmental data (including climate and topography data), and the performance of each network model was assessed using the mean estimation error (MEE), model efficiency factor $(M E F)$, and correlation coefficient $(r)$. The best neural network model was then selected and further applied to predict the forage production of rangelands in the future (in 2030 and 2080) under A1B climate change scenario using Hadley Centre coupled model. The present and future forage production maps were also produced. Rangeland forage production exhibited strong correlations with environmental factors, such as slope, elevation, aspect and annual temperature. The present forage production in the study area varied from 25.6 to $574.1 \mathrm{~kg} / \mathrm{hm}^{2}$. Under climate change scenario, the annual temperature was predicted to increase and the annual precipitation was predicted to decrease. The prediction maps of forage production in the future indicated that the area with low level of forage production $\left(0-100 \mathrm{~kg} / \mathrm{hm}^{2}\right)$ will increase while the areas with moderate, moderately high and high levels of forage production $\left(\geq 100 \mathrm{~kg} / \mathrm{hm}^{2}\right)$ will decrease both in 2030 and in 2080 , which may be attributable to the increasing annual temperature and decreasing annual precipitation. It was predicted that forage production of rangelands will decrease in the next couple of decades, especially in the western and southern parts of Isfahan Province. These changes are more pronounced in elevations between 2200 and $2900 \mathrm{~m}$. Therefore, rangeland managers have to cope with these changes by holistic management approaches through mitigation and human adaptations.
\end{abstract}

Keywords: rangelands; forage production; climate change scenario; generalized regression neural network; Central Iran

Citation: Zahra JABERALANSAR, Mostafa TARKESH, Mehdi BASSIRI, Saeid POURMANAFI. 2017. Modelling the impact of climate change on rangeland forage production using a generalized regression neural network: a case study in Isfahan Province, Central Iran. Journal of Arid Land, 9(4): 489-503. doi: 10.1007/s40333-017-0058-7

*Corresponding author: Zahra JABERALANSAR (E-mail: z.jaberalansar@na.iut.ac.ir)

Received 2016-07-27; revised 2017-03-27; accepted 2017-04-13

(C) Xinjiang Institute of Ecology and Geography, Chinese Academy of Sciences, Science Press and Springer-Verlag Berlin Heidelberg 2017 


\section{Introduction}

A rangeland is defined as 'a tract of land that is used for grazing by livestock or wildlife, where natural vegetation is the main forage resource' (FAO, 1992). Rangelands serve a variety of social and natural service functions, including provisioning services, carbon sequestration, biodiversity protection, and conservation incentives. As one of the main components of global sustainability (Havstad et al., 2007; Reynolds et al., 2007; Munasinghe, 2009), rangelands significantly contributes to food security and human welfare (Scurlock et al., 2002; O'Mara, 2012). Forage production, known as an important ecological index of rangeland ecosystems, is widely used to evaluate rangeland conditions, rangeland productivity, rangeland management, etc. (Humphrey, 1949; Torell et al., 1990; Schuur and Matson, 2001; Luo et al., 2002). Monitoring of rangeland forage production at specified spatial and temporal scales is essential to rangeland conservation (Holechek, 1988; Miehe et al., 2010).

Climate is the most important factor controlling the composition, distribution, structure and forage production of rangeland ecosystems (Gang et al., 2015). Many researchers have reported the intrinsic relationships between vegetation attributes of rangelands (including forage production) and climate variables (Smoliak, 1956; Cable, 1975; Lauenroth and Sala, 1992; Sitch et al., 2003; Krinner et al., 2005; González-Megías and Menéndez, 2012; Mowll et al., 2015; Smith et al., 2015; $\mathrm{Wu}$ et al., 2015). Among the climate variables, precipitation and temperature are the most important factors impacting the forage production of rangelands (George et al., 1989; Melillo et al., 1993; Knapp and Smith, 2001; Nemani et al., 2003). Long-term monitoring experiments are the most reliable ways to investigate the impacts of precipitation and temperature on forage production. For example, Abdollahi et al. (2012) studied the responses of forage production of dominant plant species to climate variables (including precipitation and temperature) from 2000 to 2008 at steppe rangelands in Central Iran and found that the total annual forage production of Artemisia sieberi and Salsola tomentosa was influenced by precipitation in the period from preceding December to succeeding March and by the maximum temperature in July of the succeeding year. For another example, Ehsani et al. (2007) studied the effect of climatic factors on forage production of steppe rangelands from 1998 to 2005 in Markazi Province of Iran, and the results showed that the precipitation of the preceding year and the precipitation of the succeeding growing season are the most effective factors influencing forage production.

Climate change is an indisputable fact that has drawn attention to the need for studying its impacts on various ecosystems. According to the IPCC report (IPCC, 2007), global mean air temperature increased up to $0.74^{\circ} \mathrm{C}$ during 1906 to 2005 , and is forecasted to rise up to $1.8^{\circ} \mathrm{C}-4.0^{\circ} \mathrm{C}$ during $2090-2099$. The responses of vegetation to climate change is always one of the foci in ecology (Steffen et al., 1992). Understanding the relationships between vegetation processes and climate change is important for vegetation conservation and ecosystem biodiversity preservation (Han et al., 2015). Natural ecosystems are affected by climate change in different forms, and rangelands tend to be particularly sensitive to climate change (Rummukainen, 2012; Gao et al., 2013; Mowll et al., 2015). For example, a simulation estimate conducted by Christensen et al. (2004) showed that the aboveground net primary production of grasslands will decrease by $\sim 22 \%$ under moderate grazing in Northeast Asia if temperature increased slightly and precipitation decreased slightly. Köchy et al. (2008) and Shaw et al. (2011) reported that climate change would undoubtedly influence the forage production of rangelands. All in all, understanding the forage production of rangelands is essential to sustainable rangeland management and ecosystem sustainability, especially under the context of climate change.

The statistical techniques (including machine-learning techniques) and the Geographic Information System (GIS) techniques have been widely applied in ecology to assess the impact of climate changes on the spatial distribution of organism attributes (Guisan and Zimmerman, 2000; Ray et al., 2011; Tanaka et al., 2012; Khanum et al., 2013; Lee et al., 2013; Ardestani et al., 2015). The machine-learning techniques (such as artificial neural network (ANN) and maximum entropy approaches) have been widely used in ecological modelling (see Cutler et al., 2012). ANN comprises a series of interconnected neurons that process input signals and describes the 
nonlinear and complex relationships between biophysical variables and vegetation attributes (Lek and Guégan, 1999; Olden et al., 2008). It is a widely-used approach in plant ecology, especially in predictive geographical modelling of plant ecology (Wilds et al., 2000; Linderman et al., 2004; Ingram et al., 2005; Cutler et al., 2012).

Arid and semi-arid rangelands are especially sensitive to climate change (Kawada et al., 2012). In Iran, arid and semi-arid rangelands occupy a considerable proportion of the country's territory. Isfahan Province is a representative rangeland region in Iran, which has received more attention in climatic change studies due to the livelihoods of $300 \times 10^{3}$ people depending on rangeland services, especially forage production. The aim of this study was to explore the impacts of climate change on rangeland forage production in Isfahan Province. We hope that this study may provide the needed scientific references to rangeland management in this region and other similar regions.

\section{Study area and methods}

\subsection{Study area}

The study area is the whole Isfahan Province, Central Iran (30 42'07" $-34^{\circ} 30^{\prime} 37^{\prime \prime N}$, $49^{\circ} 38^{\prime} 18^{\prime \prime}-55^{\circ} 30^{\prime} 18^{\prime \prime E}$; Fig. 1). It covers an area of $0.107 \times 10^{6} \mathrm{~km}^{2}$. In Isfahan Province, rangelands mainly distribute in the western and southwestern parts, while a vast desert distributes in the eastern and northeastern parts (i.e., the Central Iranian Desert). This desert region is mostly occupied by Playa, barren lands, dunes and lands with low vegetation coverage $(<5 \%)$. The dominant plant species in the study area are Artemisia sieberi Besser (Asteraceae) and A. aucheri Boiss in steppe rangelands, and Bromus tomentelus Boiss (Poaceae) and Elymus intermedium Host (Poaceae) in semi-steppe rangelands. There are steep gradients for climate and topography from east to west of Isfahan Province, i.e., average annual precipitation increasing from 60 to $1300 \mathrm{~mm}$, annual average temperature decreasing from $22^{\circ} \mathrm{C}$ to $4{ }^{\circ} \mathrm{C}$, and altitude increasing from 500 to more than $4000 \mathrm{~m}$ a.s.l.

(a)

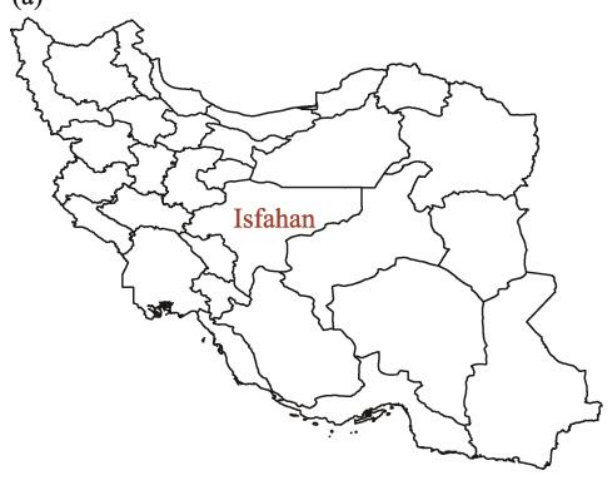

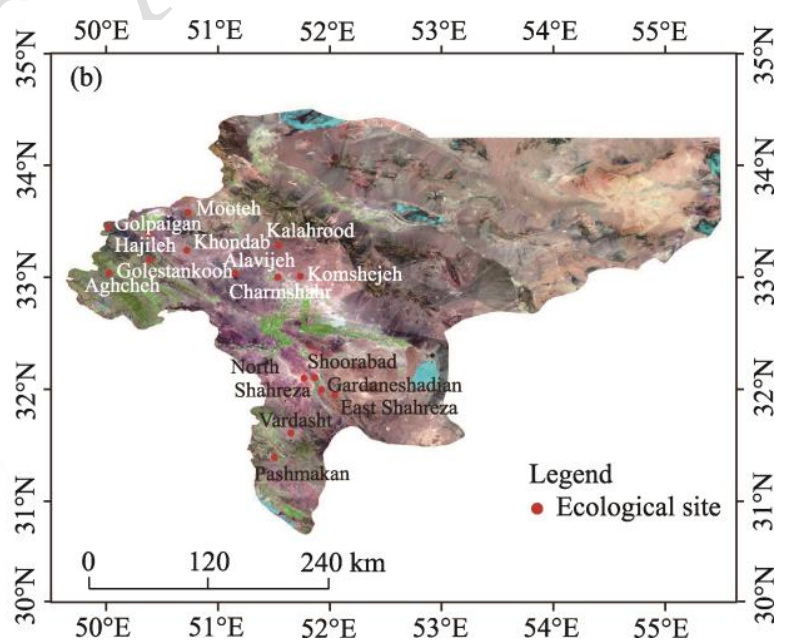

Fig. 1 Locations of Isfahan Province in Iran (a) and ecological sites in Isfahan Province (b)

\subsection{Data collection}

\subsubsection{Forage production data}

There were 16 long-term ecological sites in the study area, and each of them covered a relatively small area and was subjected to the same rangeland management practices and natural disturbances (Brown and MacLeod, 2011). Characteristics of the 16 ecological sites are shown in Table 1. Soil physical and chemical properties of the 16 ecological sites were different, resulting in distinct plant community types and forage productions. It should be stated that those ecological sites distributed in the central, western and southwestern parts could best represent the varieties of 
the forage production of rangelands in the whole Isfahan Province. Forage production for each ecological site was measured at the time of peak standing crop (i.e., May-June) during the period 1998-2007 (a total of 115 data records) using double sampling method (Wilm et al., 1944; Francis et al., 1979; Ahmed et al., 1983). There were four steps for estimating the forage production: (1) approximately estimating the forage production (weight) of several randomly selected sampling plots in the field; (2) accurately measuring the forage production (weight) of these sampling plots by clipping and weighting; (3) determining the relationship between the approximate estimations and the accurate measurements using regression analysis; and (4) estimating the forage production (weight) of all ecological sites based on their relationship (Ahmed et al., 1983). For each ecological site, four parallel transects with a length of $100 \mathrm{~m}$ each and 60 quadrates with an area of $1 \mathrm{~m} \times 2 \mathrm{~m}$ each (i.e., 15 quadrates per transect) were established using the randomized systematic sampling method to measure the forage production (Elzinga et al., 1998).

Table 1 Characteristics of the 16 ecological sites in the study area

\begin{tabular}{|c|c|c|c|c|}
\hline Ecological site & Latitude & Longitude & Plant community type & Elevation $(\mathrm{m})$ \\
\hline Alavijeh & $33^{\circ} 02^{\prime} 24^{\prime \prime} \mathrm{N}$ & $51^{\circ} 09^{\prime} 00^{\prime \prime} \mathrm{E}$ & Ar.si-No.mu-St.ho & 1884 \\
\hline Khondab & $33^{\circ} 14^{\prime} 24^{\prime \prime} \mathrm{N}$ & $50^{\circ} 43^{\prime} 12^{\prime \prime} \mathrm{E}$ & Ar.si-St.ho-Sc.or & 2231 \\
\hline Golpaigan & $33^{\circ} 23^{\prime} 24^{\prime \prime} \mathrm{N}$ & $50^{\circ} 22^{\prime} 12^{\prime \prime} \mathrm{E}$ & Co.cy-St.in-As.go & 1906 \\
\hline Mooteh & $33^{\circ} 34^{\prime} 48^{\prime \prime} \mathrm{N}$ & $50^{\circ} 43^{\prime} 48^{\prime \prime} \mathrm{E}$ & Ar.si-St.ho-No.mu & 1929 \\
\hline Kalahrood & $33^{\circ} 17^{\prime} 24^{\prime \prime} \mathrm{N}$ & $51^{\circ} 32^{\prime} 24^{\prime \prime} \mathrm{E}$ & Ar.si-As.ve-St.ho & 2025 \\
\hline Komshejeh & $33^{\circ} 00^{\prime} 36^{\prime \prime} \mathrm{N}$ & $51^{\circ} 44^{\prime} 24^{\prime \prime} \mathrm{E}$ & No.mu-Co.pi-La.ac & 1638 \\
\hline Shoorabad & $32^{\circ} 06^{\prime} 36^{\prime \prime} \mathrm{N}$ & $51^{\circ} 51^{\prime} 36^{\prime \prime} \mathrm{E}$ & Ar.si-Ac.sc-Sc.or & 1969 \\
\hline Charmshahr & $32^{\circ} 00^{\prime} 00^{\prime \prime} \mathrm{N}$ & $51^{\circ} 31^{\prime} 48^{\prime \prime} \mathrm{E}$ & Ar.si-No.mu-Sc.or & 1650 \\
\hline North Shahreza & $32^{\circ} 00^{\prime} 00^{\prime \prime} \mathrm{N}$ & $51^{\circ} 55^{\prime} 12^{\prime \prime} \mathrm{E}$ & Co.cy-Sc.or-Ac.sc & 1861 \\
\hline Eest Shahreza & $32^{\circ} 06^{\prime} 00^{\prime \prime} \mathrm{N}$ & $51^{\circ} 46^{\prime} 12^{\prime \prime} \mathrm{E}$ & Co.fr-Sc.or-Ac.sc & 1868 \\
\hline Gardaneshadian & $31^{\circ} 57^{\prime} 00^{\prime \prime} \mathrm{N}$ & $52^{\circ} 02^{\prime} 24^{\prime \prime} \mathrm{E}$ & Eb.st-Ac.sc-Ar.si & 2078 \\
\hline Vardasht & $31^{\circ} 36^{\prime} 36^{\prime \prime} \mathrm{N}$ & $51^{\circ} 39^{\prime} 00^{\prime \prime} \mathrm{E}$ & Br.to-Co.cy-As.ce & 2463 \\
\hline Pashmakan & $31^{\circ} 23^{\prime} 24^{\prime \prime} \mathrm{N}$ & $51^{\circ} 30^{\prime} 00^{\prime \prime} \mathrm{E}$ & As.su-Da.mu-El.ge & 2769 \\
\hline Aghcheh & $33^{\circ} 02^{\prime} 24^{\prime \prime} \mathrm{N}$ & $50^{\circ} 01^{\prime} 48^{\prime \prime} \mathrm{E}$ & As.br-Er.bi-Ci.br & 2707 \\
\hline Golestankooh & $33^{\circ} 09^{\prime} 36^{\prime \prime} \mathrm{N}$ & $50^{\circ} 23^{\prime} 24^{\prime \prime} \mathrm{E}$ & As.br-El.in-As.ve & 2747 \\
\hline Hajileh & $33^{\circ} 27^{\prime} 00^{\prime \prime} \mathrm{N}$ & $50^{\circ} 01^{\prime} 12^{\prime \prime} \mathrm{E}$ & As.ve-Co.cy-St.ho & 2388 \\
\hline
\end{tabular}

Note: Arsi: Artemisia sieberi; No.mu: Noaea mucronata; St.ho: Stipa hohenackeriana; Sc.or: Scariola orientalis; Co.cy: Cousinia cylindracea; St.in: Stachys inflata; As.go: Astragalus gossypinus; As.ve: Astragalus verus; Co.pi: Cousinia piptocephala; La.ac: Launaea acanthodes; Ac.sc: Acantholimon scorpius; Co.fr: Convolvulus fruticosus; Eb.st: Ebenus stellata; Br.to: Bromus tomentellus; As.ce: Astragalus cephalanthus; As.su: Astragalus susianus; Da.mu: Daphne mucronata; El.ge: Elymus gentryi; As.br: Astragalus brachycalyx; Er.bi: Eryngium billardieri; Ci.br: Cirsium bracteosum; El.in: Elymus intermedium.

\subsubsection{Environmental data}

A total of 19 bioclimatic variables (Bio1-Bio19) were produced using data from 32 meteorological stations (Iran Meteorological Organization; http://www.irimo.ir) in the study area by Terrset software (https://clarklabs.org/terrset/) combined with geostatistical methods. The topographical variables (including elevation, aspect, and slope) were derived from the digital elevation model (DEM). The aspect variable was transformed from a circular variable to a linear variable using Equation 1 (Beers et al., 1966), and its range varied from 0 (azimuth of $225^{\circ}$ ) to 2 (azimuth of $45^{\circ}$ ).

Transformed aspect $=\cos (45-$ Aspect $)+1$.

Pearson's correlation analysis was applied to exclude bioclimatic variables that were highly inter-correlated $(r \geq \pm 0.8)$ in the modelling process of the generalized regression neural network (GRNN). Finally, a total of 12 bioclimatic variables combined with 3 topographical variables were selected (Table 2). Environmental maps were converted into ASCII Grid format with the same pixel size and projection (spatial resolution of $1 \mathrm{~km}^{2}$, WGS84). For each ecological site, values of environmental variables were extracted by query operation in the Geographic Information System (GIS). 
Table 2 Definition and importance of the selected environmental variables in the generalized regression neural network (GRNN) model

\begin{tabular}{clrr}
\hline Code & Definition & Rank & Ratio \\
\hline Bio1 & Annual mean temperature $\left({ }^{\circ} \mathrm{C}\right)$ & 4 & 1.079 \\
Bio3 & Isothermality $(($ Bio2/Bio7) $\times 100)$ & 14 & 0.976 \\
Bio5 & Maximum temperature of warmest month $\left({ }^{\circ} \mathrm{C}\right)$ & 12 & 0.994 \\
Bio6 & Minimum temperature of coldest month $\left({ }^{\circ} \mathrm{C}\right)$ & 5 & 1.047 \\
Bio7 & Temperature annual range $\left(\right.$ Bio5-Bio6; $\left.{ }^{\circ} \mathrm{C}\right)$ & 9 & 1.015 \\
Bio8 & Mean temperature of wettest quarter $\left({ }^{\circ} \mathrm{C}\right)$ & 15 & 0.974 \\
Bio9 & Mean temperature of driest quarter $\left({ }^{\circ} \mathrm{C}\right)$ & 7 & 1.024 \\
Bio12 & Annual precipitation $(\mathrm{mm})$ & 8 & 1.019 \\
Bio13 & Precipitation of wettest quarter $(\mathrm{mm})$ & 11 & 1.005 \\
Bio16 & Precipitation of wettest quarter $(\mathrm{mm})$ & 6 & 1.031 \\
Bio17 & Precipitation of driest quarter $(\mathrm{mm})$ & 13 & 0.988 \\
Bio18 & Precipitation of warmest quarter $(\mathrm{mm})$ & 10 & 1.007 \\
Elevation & Elevation $(\mathrm{m})$ & 2 & 1.213 \\
Slope & Slope $(\%)$ & 1 & 1.284 \\
Aspect & Aspect & 3 & 1.160 \\
\hline
\end{tabular}

\subsection{Future climate change scenario}

Climate variables projected under A1B climate change scenario from a general circulation model (Hadley Centre coupled model (HadCM3)) for two time periods, i.e., 2021-2040 (denoted as 2030) and 2071-2090 (denoted as 2080), were obtained (IPCC, 2013). The A1B climate change scenario describes a future world with very sharp economic growth, with global population peaking in the mid-century and with rapid introduction of new and more efficient technologies (Hanafin et al., 2011). This scenario assumes balances across all sources of technologies (Prudhomme et al., 2010).

\subsection{Generalized regression neural network}

In this study, a generalized regression neural network (GRNN) was applied to predict rangeland forage production in relation to environmental variables by Statistica software version 7.0 (Statsoft, Tulsa, OK, USA). GRNN is a variation of the radial basis neural networks, which is based on kernel regression networks (Celikoglu, 2006; Cigizoglu and Alp, 2006). Unlike the back propagation networks, GRNN does not require an iterative training procedure. It approximates any arbitrary function between input and output vectors, drawing the function estimate directly from the training data (Hannan et al., 2010). A GRNN consists of four layers: input layer, pattern layer, summation layer, and output layer. The system learns iteratively through predicting output layer from input layer using a set of training data (Cohn et al., 1996). In this study, training error was fixed at 0.0012 and two hidden layers with 61 neurons were selected in the modelling process. The final model was translated into geographical space using ArcGIS software version 10.1. Forage production in the final maps was classified into four levels: high level $\left(>500 \mathrm{~kg} / \mathrm{hm}^{2}\right)$, moderately high level $\left(300-500 \mathrm{~kg} / \mathrm{hm}^{2}\right)$, moderate level $\left(100-300 \mathrm{~kg} / \mathrm{hm}^{2}\right)$ and low level $(0-100$ $\mathrm{kg} / \mathrm{hm}^{2}$ ). Figure 2 demonstrates the steps of the modelling process for predicting the future forage production in this study.

\subsection{Model evaluation}

The performance of the GRNN model was evaluated using forage production data measured during 2014 and 2015 from 19 additional ecological sites in the study area (not shown in Fig. 1). The mean estimation error $(M E E)$, model efficiency factor $(M E F)$, and correlation coefficient $(r)$ between the measured and the predicted values for the testing datasets were used to evaluate the performance of the GRNN model. The $M E E$ and $M E F$ statistics were calculated as follows:

$$
M E E=\frac{1}{n} \sum_{i=1}^{n}\left[P\left(x_{i}\right)-M\left(x_{i}\right)\right],
$$




$$
M E F=1-\frac{\sum_{i=1}^{n}\left[P\left(x_{i}\right)-M\left(x_{i}\right)\right]^{2}}{\sum_{i=1}^{n}\left[M\left(x_{i}\right)-\bar{M}\left(x_{i}\right)\right]^{2}},
$$

where, $P\left(x_{i}\right)$ is the predicted value; $M\left(x_{i}\right)$ is the measured value; $\bar{M}\left(x_{i}\right)$ is the mean of the measured values; and $n$ is the total number of measurements.

(1) Ecological site locations
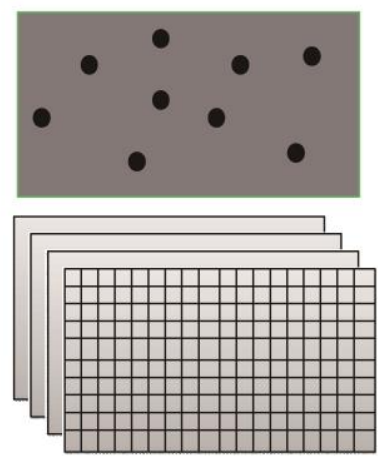

(2) Environmental variables
(3) Data matrix

\begin{tabular}{|c|l|c|c|c|c|}
\hline & \multicolumn{5}{|c|}{ Environmental variables } \\
\hline \multirow{2}{*}{ Location } & $\begin{array}{l}\text { Forage } \\
\text { production }(y)\end{array}$ & $\begin{array}{r}\text { Bio1 } \\
(x 1)\end{array}$ & $\begin{array}{r}\text { Bio3 } \\
(x 3)\end{array}$ & $\begin{array}{c}\text { Bio5 } \\
(x 5)\end{array}$ & $\ldots$ \\
\hline 1 & & & & & \\
\hline 2 & & & & & \\
\hline 3 & & & & & \\
\hline 4 & & & & & \\
\hline$\ldots$ & & & & & \\
\hline
\end{tabular}

옹

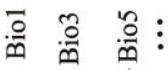
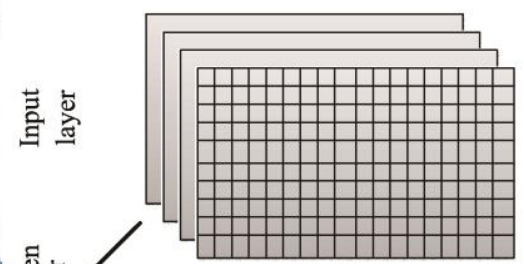

(6) Climate change variables

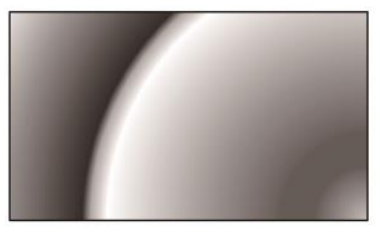

(7) Future forage production map

Fig. 2 Steps of the modelling process for predicting the rangeland forage production using a generalized regression neural network (GRNN) model. Georeferenced ecological sites (1) during the study period were linked with the digital maps of environmental variables (2); Values of environmental variables for each ecological site location were extracted (3); A GRNN model defines the relationship between records of forage production and environmental variables (4); The best model was selected and applied to environmental maps to produce the present forage production map (5), and it was also applied to project the future forage production map under A1B climate change scenario $(6,7)$.

\subsection{Statistical analysis}

We used one-way analysis of variance (ANOVA; including Kruskal-Wallis H test and Turkey's test) to assess the differences in forage production and climatic data under different climate conditions. The Kruskal-Wallis $\mathrm{H}$ test is a non-parametric method for testing whether groups originate from the same distribution. The Kruskal-Wallis $\mathrm{H}$ test does not assume a normal distribution of the residuals. It is used for comparing two or more independent groups with equal or different sizes. The null hypothesis $\left(\mathrm{H}_{0}\right)$ means that the medians of all groups are equal, and the alternative hypothesis $\left(\mathrm{H}_{1}\right)$ means that one group is different from the median of at least one other group (Zar, 2010). The Turkey's test is one of the famous mean comparison tests. Difference was considered significant at the $P<0.05$ level. 


\section{Results}

\subsection{Present and future forage productions}

3.1.1 Present and future forage productions in different ecological sites of the study area The present forage production (during 1998-2007) and future forage production (in 2030 and 2080) in different ecological sites are shown in Table 3. It can be seen that the present forage production was highest in Golestankooh site $\left(477.4 \mathrm{~kg} / \mathrm{hm}^{2}\right)$, followed by Aghcheh site (473.0 $\mathrm{kg} / \mathrm{hm}^{2}$ ) and Pashmakan site $\left(335.2 \mathrm{~kg} / \mathrm{hm}^{2}\right)$. Forage productions in the future (in 2030 and 2080) under A1B climate change scenario for the 16 ecological sites (with an exception of Pashmakan site in 2080) were all lower than those at present (1998-2007). Hajileh site showed the largest decreasing trend of forage production in the future, and Aghcheh site exhibited the highest forage production in the future.

Table 3 Present and future forage productions as well as the changes of forage production under A1B climate change scenario in different ecological sites of the study area

\begin{tabular}{|c|c|c|c|c|c|}
\hline \multirow{3}{*}{ Ecological site } & \multicolumn{3}{|c|}{ Forage production $\left(\mathrm{kg} / \mathrm{hm}^{2}\right)$} & \multicolumn{2}{|c|}{ Change of forage production $(\%)$} \\
\hline & \multirow{2}{*}{$\begin{array}{c}\text { Present } \\
(1998-2007)\end{array}$} & \multicolumn{2}{|c|}{ Future } & \multirow{2}{*}{ Present to 2030} & \multirow{2}{*}{ Present to 2080} \\
\hline & & 2030 & 2080 & & \\
\hline Alavijeh & 82.7 & 73.2 & 74.4 & -11.5 & -10.1 \\
\hline Khondab & 173.0 & 118.9 & 95.3 & -31.3 & -44.9 \\
\hline Golpaigan & 104.7 & 91.6 & 61.0 & -12.5 & -41.7 \\
\hline Mooteh & 112.2 & 95.5 & 62.5 & -14.9 & -44.3 \\
\hline Kalahrood & 95.9 & 87.4 & 80.9 & -8.9 & -15.7 \\
\hline Komshejeh & 73.3 & 65.7 & 62.4 & -10.3 & -14.9 \\
\hline Shoorabad & 123.1 & 105.4 & 80.3 & -14.4 & -34.7 \\
\hline Charmshahr & 76.1 & 67.8 & 63.7 & -11.0 & -16.4 \\
\hline North Shahreza & 94.2 & 74.9 & 51.5 & -20.5 & -45.4 \\
\hline Eest Shahrez & 95.0 & 75.6 & 53.3 & -20.4 & -43.8 \\
\hline Gardaneshadian & 121.7 & 103.0 & 70.1 & -15.4 & -42.4 \\
\hline Vardasht & 199.2 & 187.2 & 147.9 & -6.0 & -25.8 \\
\hline Pashmakan & 335.2 & 258.8 & 337.4 & -22.8 & +0.7 \\
\hline Aghcheh & 473.0 & 449.9 & 419.1 & -4.9 & -11.4 \\
\hline Golestankooh & 477.4 & 433.2 & 332.5 & -9.3 & -30.4 \\
\hline Hajileh & 239.3 & 127.8 & 92.6 & -46.6 & -61.3 \\
\hline
\end{tabular}

3.1.2 Present and future forage productions in different elevations of the study area

Elevation is one of the important environmental factors influencing the forage production. Forage production in different elevations at present (during 1998-2007) and in the future (in 2030 and 2080) showed that the amount of forage production is likely to change more dramatically in elevations between 2200 and $2900 \mathrm{~m}$ in the future under A1B climate change scenario, while it is predicted to remain unchanged or change only slightly in elevations below $1700 \mathrm{~m}$ and above $3200 \mathrm{~m}$ (Fig. 3). Under A1B climate change scenario, forage production in the medium elevations $(2200-2600 \mathrm{~m})$ will decrease by $22.4 \%$ and $41.2 \%$ in the years 2030 and 2080, respectively (Table 4).

3.1.3 Present and future forage productions in the whole study area

The present forage production map in the whole study area (i.e., Isfahan Province) showed that the values of forage production ranged from 25.6 to $574.1 \mathrm{~kg} / \mathrm{hm}^{2}$ (Fig. 4a). The areas with moderately high and high levels of forage production $\left(\geq 300 \mathrm{~kg} / \mathrm{hm}^{2}\right)$ were distributed in the western and southern parts, while the area with moderate level of forage production (100-300 $\mathrm{kg} / \mathrm{hm}^{2}$ ) was distributed along a narrow strip in the central part of the study area. Furthermore, the 


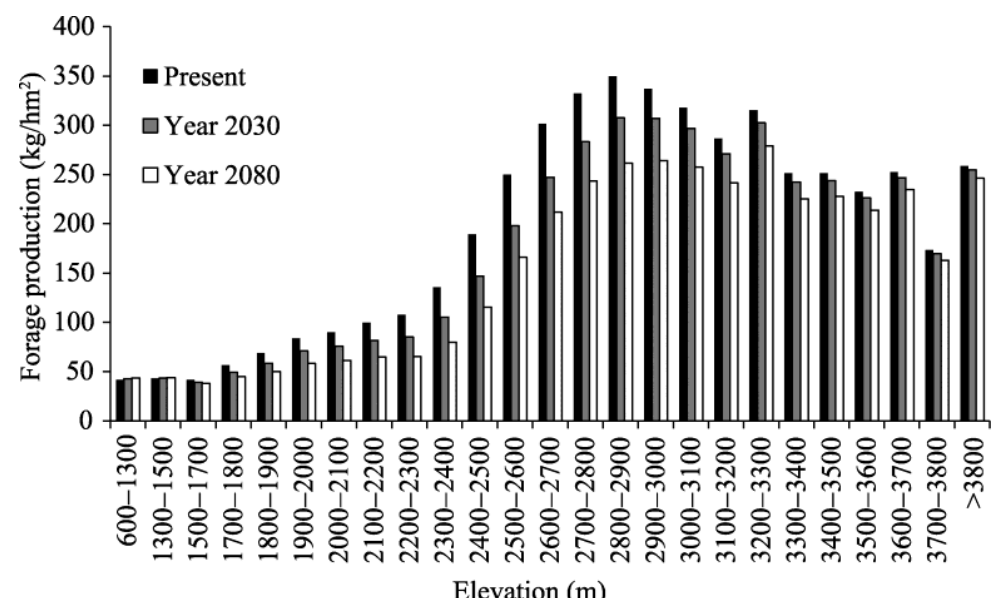

Elevation (m)

Fig. 3 Present forage production (during 1998-2007) and future forage production (in 2030 and 2080) in different elevations of the study area

Table 4 Present and future forage productions and the changes of forage production under A1B climate change scenario in different elevations of the study area

\begin{tabular}{|c|c|c|c|c|c|}
\hline \multirow{3}{*}{ Elevation (m) } & \multicolumn{3}{|c|}{ Forage production $\left(\mathrm{kg} / \mathrm{hm}^{2}\right)$} & \multicolumn{2}{|c|}{ Change of forage production $(\%)$} \\
\hline & \multirow{2}{*}{$\begin{array}{c}\text { Present } \\
(1998-2007)\end{array}$} & \multicolumn{2}{|c|}{ Future } & \multirow{2}{*}{ Present to 2030} & \multirow{2}{*}{ Present to 2080} \\
\hline & & 2030 & 2080 & & \\
\hline $600-1300$ & 41.9 & 42.8 & 43.4 & +1.9 & +3.4 \\
\hline $1300-1500$ & 43.2 & 43.5 & 44.2 & +0.7 & +2.3 \\
\hline $1500-1700$ & 41.9 & 39.2 & 38.2 & -6.67 & -8.9 \\
\hline $1700-1800$ & 56.8 & 49.4 & 45.0 & -13.1 & -20.8 \\
\hline 1800-1900 & 68.9 & 58.7 & 50.1 & -14.8 & -27.4 \\
\hline $1900-2000$ & 83.8 & 71.3 & 58.4 & -14.9 & -30.3 \\
\hline $2000-2100$ & 89.8 & 75.8 & 61.4 & -15.6 & -31.6 \\
\hline $2100-2200$ & 99.8 & 81.7 & 65.0 & -18.1 & -34.8 \\
\hline $2200-2300$ & 107.8 & 85.1 & 65.3 & -21.1 & -39.4 \\
\hline $2300-2400$ & 135.6 & 105.4 & 79.7 & -22.3 & -41.2 \\
\hline $2400-2500$ & 189.4 & 147.0 & 115.4 & -22.4 & -39.1 \\
\hline $2500-2600$ & 250.0 & 198.2 & 165.9 & -20.7 & -33.6 \\
\hline $2600-2700$ & 301.5 & 247.2 & 211.8 & -18.0 & -29.7 \\
\hline $2700-2800$ & 332.5 & 283.2 & 243.5 & -14.8 & -26.8 \\
\hline 2800-2900 & 349.8 & 307.5 & 261.8 & -12.1 & -25.2 \\
\hline $2900-3000$ & 337.1 & 307.0 & 264.4 & -8.9 & -21.6 \\
\hline $3000-3100$ & 317.9 & 296.9 & 257.5 & -6.6 & -19.0 \\
\hline $3100-3200$ & 286.6 & 271.2 & 241.6 & -5.4 & -15.7 \\
\hline $3200-3300$ & 315.4 & 302.4 & 279.2 & -4.1 & -11.5 \\
\hline $3300-3400$ & 251.2 & 242.4 & 225.5 & -3.5 & -10.2 \\
\hline $3400-3500$ & 251.3 & 243.7 & 228.1 & -3.0 & -9.3 \\
\hline $3500-3600$ & 232.8 & 226.4 & 213.6 & -2.7 & -8.2 \\
\hline $3600-3700$ & 252.5 & 246.7 & 235.0 & -2.3 & -6.9 \\
\hline $3700-3800$ & 173.6 & 169.9 & 162.7 & -2.1 & -6.2 \\
\hline$>3800$ & 258.9 & 254.8 & 246.3 & -1.6 & -4.9 \\
\hline
\end{tabular}

area with low level of forage production $\left(0-100 \mathrm{~kg} / \mathrm{hm}^{2}\right)$ was observed in the northern, eastern and southeastern parts of the study area, including steppe rangelands and sand hills. The mean estimation error (MEE), model efficiency factor $(M E F)$, and correlation coefficient $(r)$ between 
the measured and the predicted values were $2.99 \mathrm{~g} / \mathrm{hm}^{2}, 0.60$, and 0.76 , respectively.

The future forage production maps under A1B climate change scenario showed that the values of forage production will vary from 25.4 to $567.5 \mathrm{~kg} / \mathrm{hm}^{2}$ and 26.2 to $553.2 \mathrm{~kg} / \mathrm{hm}^{2}$ for the years 2030 and 2080, respectively (Figs. 4b and c). Compared to the present conditions, the area with low level of forage production in the future under A1B climate change scenario will increase by $11.2 \%$ for the year 2030 and by $21.8 \%$ for the year 2080 (Table 5). In contrast, the areas with moderate, moderately high, and high levels of forage production will significantly decrease in the future under A1B climate change scenario.

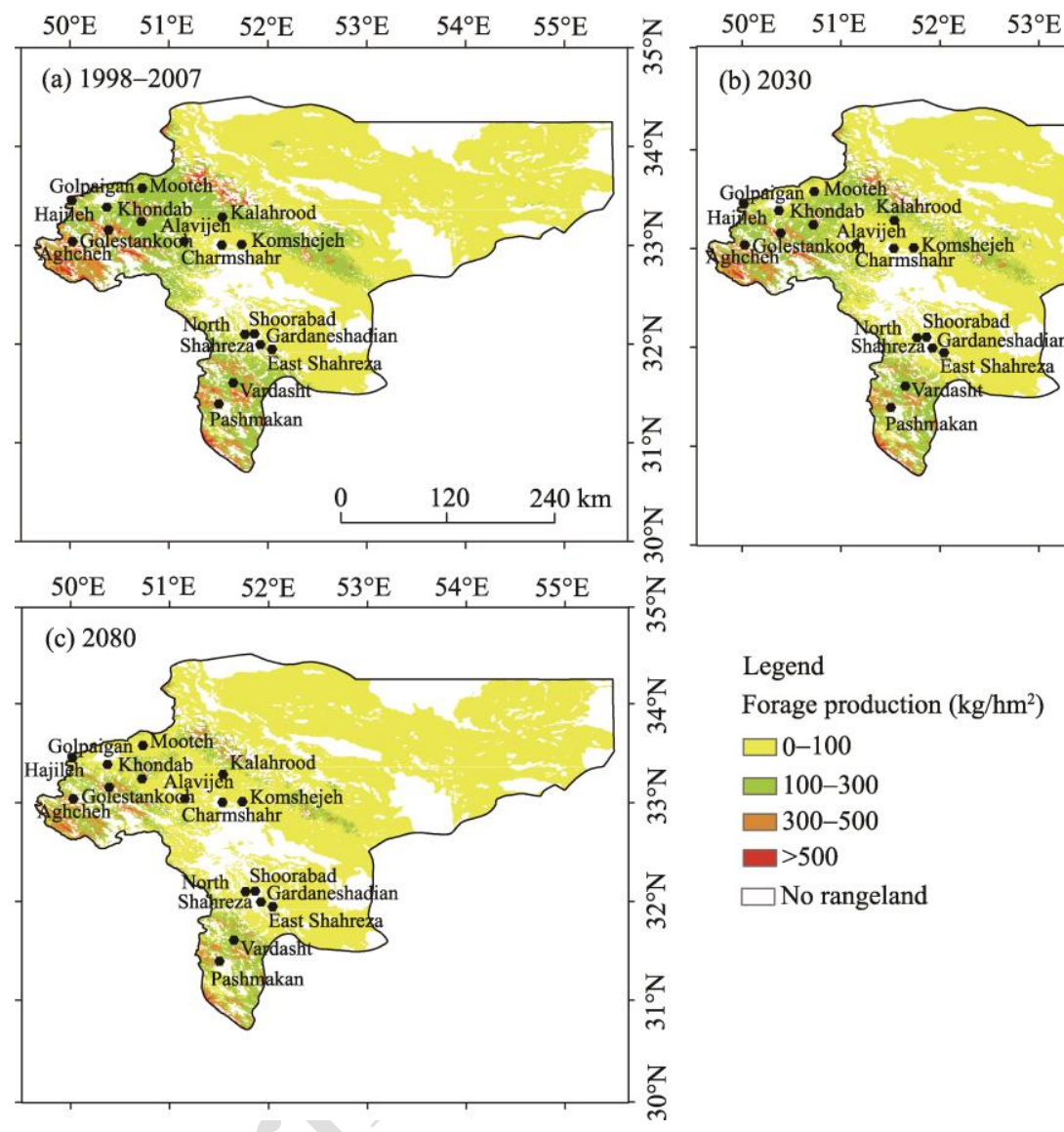

Fig. 4 Present forage production map (a) and future forage production maps (b, c) under A1B climate change scenario in the whole study area

Table 5 Areas with different levels of forage production at present and in the future and the changes of areas under A1B climate change scenario in the whole study area

\begin{tabular}{|c|c|c|c|c|c|c|}
\hline \multirow{3}{*}{ Forage production $\left(\mathrm{kg} / \mathrm{hm}^{2}\right)$} & \multirow{3}{*}{ Level } & \multicolumn{3}{|c|}{ Area $\left(\mathrm{hm}^{2}\right)$} & \multicolumn{2}{|c|}{ Change of area $(\%)$} \\
\hline & & \multirow{2}{*}{$\begin{array}{c}\text { Present } \\
(1998-2007)\end{array}$} & \multicolumn{2}{|c|}{ Future } & \multirow{2}{*}{ Present to 2030} & \multirow{2}{*}{ Present to 2080} \\
\hline & & & 2030 & 2080 & & \\
\hline $0-100$ & Low & $5,278,228.0$ & $5,868,063.8$ & $6,429,413.9$ & +11.2 & +21.8 \\
\hline $100-300$ & Moderate & $1,641,698.4$ & $1,222,927.8$ & $760,674.9$ & -25.5 & -53.7 \\
\hline $300-500$ & Moderately high & $529,247.1$ & $387,647.3$ & $304,903.0$ & -26.7 & -42.4 \\
\hline$>500$ & High & $52,751.4$ & $23,285.9$ & 6933.0 & -55.9 & -86.9 \\
\hline
\end{tabular}

\subsection{Relationships of forage production and environmental variables}

As shown in Table 2, four environmental variables (including slope, elevation, aspect, and annual mean temperature) exhibited high contributions in neural network process, with ratios of 1.284 , $1.213,1.160$, and 1.079, respectively. There were positive relationships of forage production with 
slope and elevation (increasing trends) while a negative relationship of forage production with annual mean temperature (a decreasing trend) was observable (Fig. 5). Generally speaking, forage productions with moderately high level $\left(300-500 \mathrm{~kg} / \mathrm{hm}^{2}\right)$ were appeared in the areas either with slope $>15 \%$, or with elevation $>2500 \mathrm{~m}$, or with annual mean temperature $<12^{\circ} \mathrm{C}$. Furthermore, the southwest aspect exhibited the highest forage production.
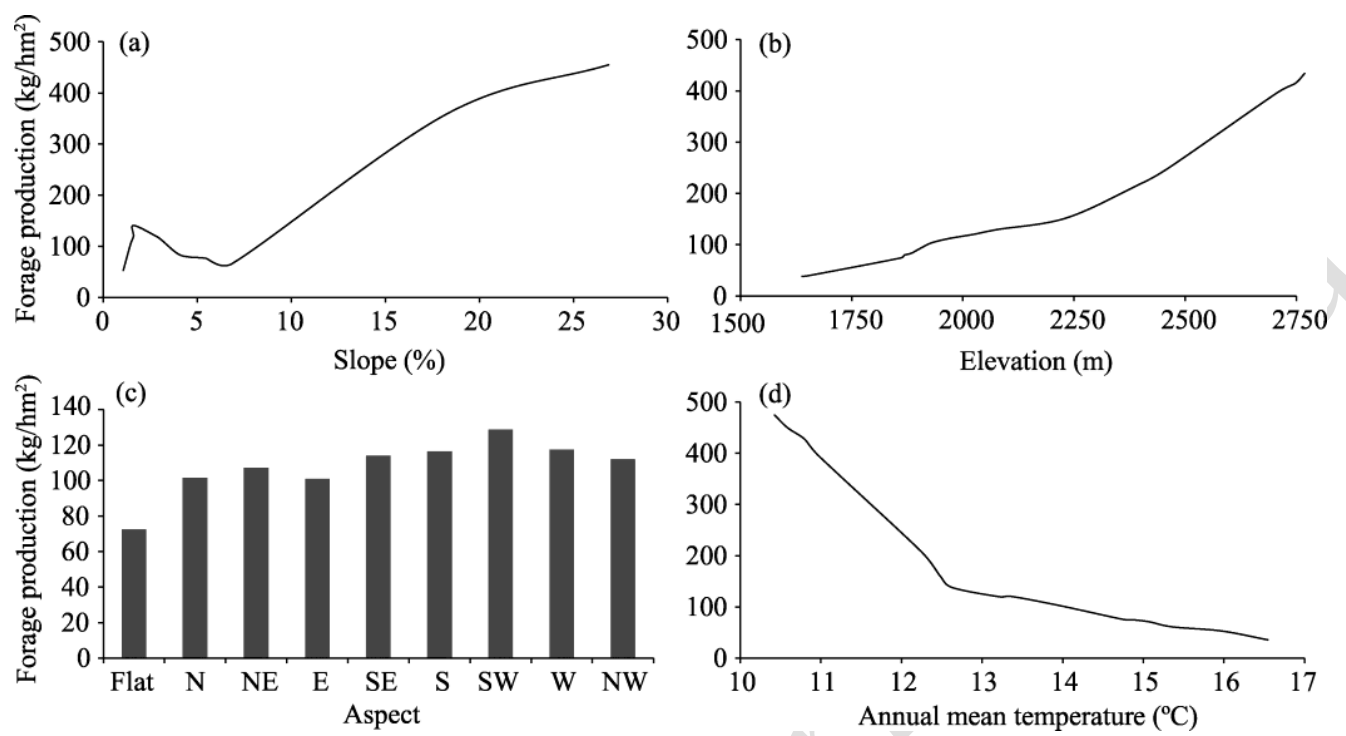

Fig. 5 Relationships of forage production with slope (a), elevation (b), aspect (c) and annual mean temperature (d)

\section{Discussion}

Rangelands in Isfahan Province cover an area of $\sim 7 \times 10^{6} \mathrm{hm}^{2}$ and occupy $60 \%$ of the total provincial area. Those rangelands provide a wide variety of ecosystem goods and services. Generally speaking, the impacts of climate change on rangelands are very complex and it would be virtually impossible to explore all aspects in a limited geographic region. In this study, rangeland forage production and the impacts of climate change on rangeland forage production were investigated using a new approach, which is based on the generalized regression neural network (GRNN) and the GIS techniques.

Rangeland forage production and its response to climate change can be used to describe the quality of rangeland ecosystems (Field et al., 1998). Our results showed that the neural model (i.e., GRNN) could successfully predict the rangeland forage production $\left(M E E=2.99 \mathrm{~g} / \mathrm{hm}^{2}, M E F=0.60\right.$, and $r=0.79$ ). The present forage production (1998-2007) varied between 25.6 and $574.1 \mathrm{~kg} / \mathrm{hm}^{2}$ in the study area (i.e., Isfahan Province). The future forage production maps showed that compared to the present conditions, the area with a low level of forage production will increase in the future (in 2030 and 2080) under A1B climate change scenario while the areas with moderate, moderately high, and high levels of forage production will decrease (Table 5; Fig. 4). As shown in Figure 4, the area with a low level of forage production will develop in the northwestern and western parts of Isfahan Province. Under A1B climate change scenario, the annual mean temperature will increase from present $13.8^{\circ} \mathrm{C}$ to $14.0^{\circ} \mathrm{C}$ in 2030 and to $17.0^{\circ} \mathrm{C}$ in 2080 (Fig. 6a); the mean annual precipitation will decrease by $43.3 \%$ and $54.5 \%$ in 2030 and 2080, respectively (Fig. 6b); and the amount of forage production will decrease by $16.0 \%$ and $27.5 \%$ in 2030 and 2080, respectively (Fig. 6c). The Tukey test showed that there was no significant difference of annual mean temperature between the present and 2030, while the different was significant between the present and $2080(P<0.001$; Fig. 6a). The Kruskal-Wallis H test showed that there were significant differences for both forage production and mean annual precipitation under different climate conditions. Since forage production is strongly correlated with climate factors in 
rangeland ecosystems, variations in temperature and precipitation are expected to significantly affect forage production. Thus, the increase of area with a low level of forage production and the decrease of areas with moderate, moderately high, and high levels of forage production in the future under A1B climate change scenario are caused by the projected increase in the annual mean temperature and the projected decrease in the annual precipitation. Some studies also have demonstrated that climate change has negative effects on vegetation production (Christensen et al., 2004; Köchy et al., 2008; Shaw et al., 2011). For example, Shaw et al. (2011) studied the effect of precipitation changes on rangeland forage production in California and suggested that the amount of forage production will decrease significantly under all climate change scenarios by the end of this century.

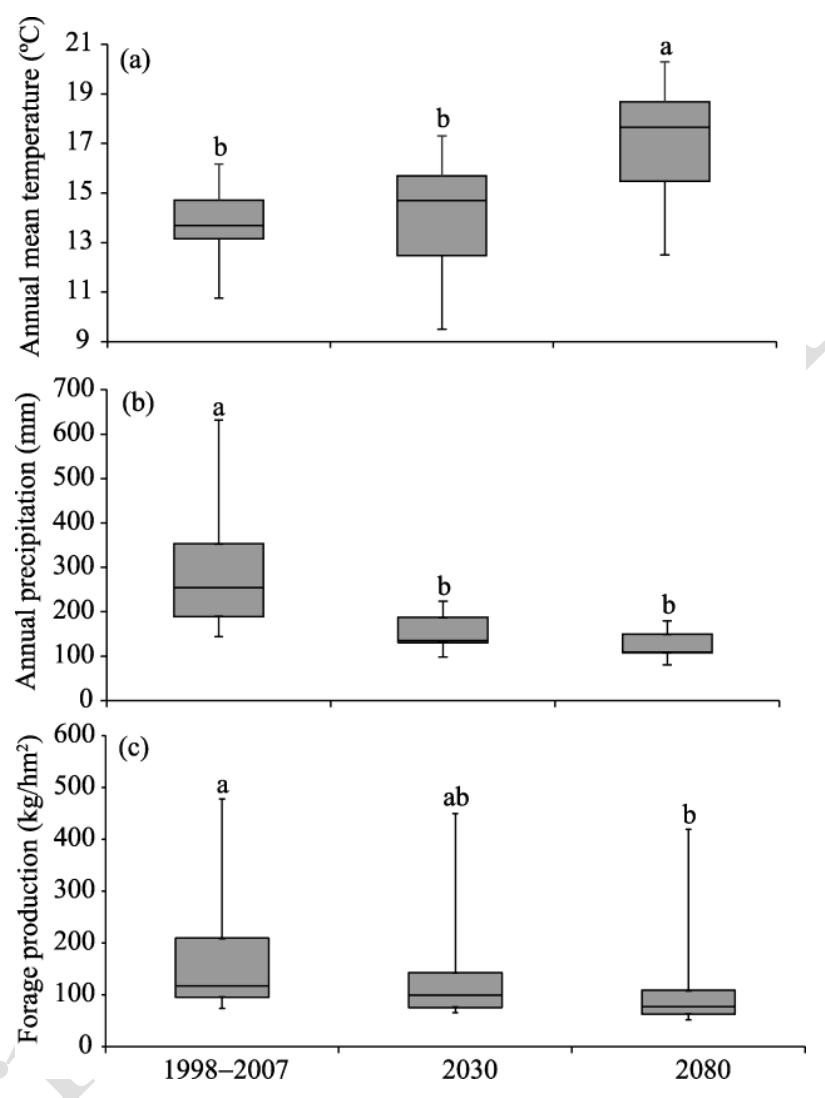

Fig. 6 Variations of annual mean temperature (a), annual precipitation (b) and forage production (c) at present (during 1998-2007) and in the future (in 2030 and 2080) under A1B climate change scenario. In these figures, the central rectangle spans the first quartile to the third quartile. The median of the data is presented by segment inside of rectangle and "whiskers" above and below the box display the locations of the minimum and maximum values, respectively. Different lowercase letters indicate significant differences $(P<0.05)$ among different climate scenarios.

It was widely reported that high temperature negatively affects the forage production due to increased evapotranspiration and decreased water availability for plants (Epstein et al., 1997; Engel et al., 2009). Liang et al. (2003) suggested that water availability is a key limiting factor that controls the net primary production of vegetation. In this study, decreasing forage production was observed more remarkably in 2080 than in 2030 in the central, western and southern parts of the study area (Figs. 7a and b). Elevation is one of the main predictive variables that affect the forage production due to its impact on such environmental factors as climatic variables (Daly et al., 2002). The present forage production map demonstrated that forage production with a moderately high level $\left(300-400 \mathrm{~kg} / \mathrm{hm}^{2}\right)$ mainly distributed in the medium elevations between 2700 and $3300 \mathrm{~m}$. This range of elevation, in the western parts of the study area, is predicted to 
remain a moderately high level of forage production by the years 2030 and 2080 under A1B climate change scenario (Table 4). Goraghani et al. (2014) also reported that the highest forage production appeared in the medium elevations.
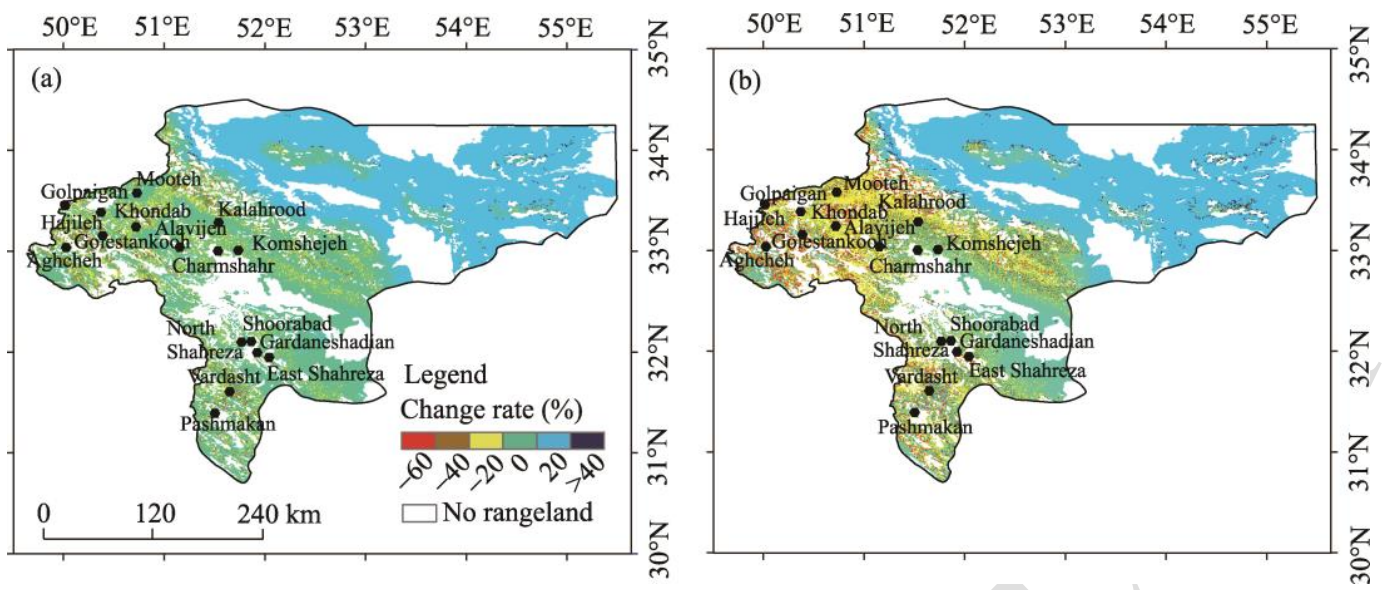

Fig. 7 Variations of rangeland forage production in 2030 (a) and 2080 (b) under A1B climate change scenario compared to the present conditions

Generally speaking, $\mathrm{C}_{3}$ plants are more sensitive to climate change than $\mathrm{C}_{4}$ and $\mathrm{CAM}$ (Crassulacean acid metabolism) plants (Rathore and Jasrai, 2013). In other words, $\mathrm{C}_{4}$ and CAM plants are more efficient because they can tolerate high temperatures (Rathore and Jasrai, 2013). We found that $\mathrm{C}_{3}$ plants are more abundant in the western part of the study area (i.e., semi-steppe rangelands), while $\mathrm{C}_{4}$ and CAM plants are widely distributed in the eastern and northeastern parts (steppe rangelands and deserts). Therefore, the semi-steppe rangelands are more sensitive to climate change than steppe rangelands and deserts in Isfahan Province.

In this study, we used a GRNN model to predict the amount of forage production in the future in Isfahan Province based on climate and topography variables without considering any connection with land management practices, such as livestock grazing and human disturbances. The results obtained from the model are suitable for regional environmental management and for rangeland forage production monitoring. The model provides key information about the environment-forage production relationship, which can be in turn helpful in identifying the susceptible regions and protection areas in Isfahan Province. Rangeland managers and conservation planners can use the outputs of this model as references for supporting livelihoods, grazing management, food security and rehabilitation of rangelands in Isfahan Province.

\section{Conclusions}

A GRNN model was used in this study to explore the variations of rangeland forage production in the future (2030 and 2080) under A1B climate change scenario in Isfahan Province, Central Iran. Our results show that the annual mean temperature will increase while the annual precipitation will decrease in 2030 and 2080. In other words, the climate would become warmer and drier in the study area. Rangeland forage production in Isfahan Province will decrease by $16.0 \%$ and $27.5 \%$ in 2030 and 2080, respectively, under A1B climate change scenario, particularly in the western and southern parts. We have also determined the key regions that might be severely affected by climate change. From a management perspective, we emphasize the needs to conduct additional field surveys to improve the prediction model and to apply conservation strategies.

\section{Acknowledgments}

This research was funded by the Isfahan University of Technology. We are grateful to Masoud BORHANI and Mohamad T FEIZI for their helpful comments and to the Research Institute of Forests and Rangelands, Isfahan, Iran for providing the ground control vegetation map. 


\section{References}

Abdollahi J, Arzani H, Naderi H, et al. 2012. Effect of precipitation and high temperature variability on forage production of some plant species in the Yazd steppe rangelands during the period of 2000-2008 (Case study: Ernan region). Arid Biome Scientific and Research Journal, 2(1): 58-69. (in Persian)

Ahmed J, Bonham C D, Laycock W A. 1983. Comparison of techniques used for adjusting biomass estimates by double sampling. Journal of Range Management, 36(2): 217-221.

Ardestani E G, Tarkesh M, Bassiri M, et al. 2015. Potential habitat modeling for reintroduction of three native plant species in central Iran. Journal of Arid Land, 7(3): 381-390.

Beers T W, Dress P E, Wensel L C. 1966. Aspect transformation in site productivity research. Journal of Forestry, 64: 691-692.

Brown J, MacLeod N. 2011. A site-based approach to delivering rangeland ecosystem services. The Rangeland Journal, 33(2): 99-108.

Cable D R. 1975. Influence of precipitation on perennial grass production in the semidesert southwest. Ecology, 56(4): 981-986.

Celikoglu H B. 2006. Application of radial basis function and generalized regression neural networks in non-linear utility function specification for travel mode choice modelling. Mathematical and Computer Modelling, 44(7-8): 640-658.

Christensen L, Coughenour M B, Ellis J E, et al. 2004. Vulnerability of the Asian typical steppe to grazing and climate change. Climatic Change, 63(3): 351-368.

Cigizoglu H K, Alp M. 2006. Generalized regression neural network in modelling river sediment yield. Advances in Engineering Software, 37(2): 63-68.

Cohn D A, Ghahramani Z, Jordan M I. 1996. Active learning with statistical models. Journal of Artificial Intelligence Research, 4: $129-145$.

Cutler M E J, Boydb D S, Foodyb G M, et al. 2012. Estimating tropical forest biomass with a combination of SAR image texture and Landsat TM data: An assessment of predictions between regions. ISPRS Journal of Photogrammetry and Remote Sensing, 70: 66-77.

Daly C, Gibson W P, Taylor G H, et al. 2002. A knowledge-based approach to the statistical mapping of climate. Climate Research, 22(2): 99-113.

Ehsani A, Farahpour M, Jalili A, et al. 2007. The effect of climatic conditions on range forage production in steppe ranglands, Akhtarabad of Saveh. Iranian Journal of Range and Desert Research, 14(2): 249-260.

Elzinga C L, Salzer D W, Willoughby J W. 1998. Measuring \& Monitoring Plant Populations. Denver, Colorado: U.S. Department of the Interior, Bureau of Land Management, National Applied Resource Sciences Center, 471. (in Persian)

Engel E C, Weltzin J F, Norby R J, et al. 2009. Responses of an old-field plant community to interacting factors of elevated $\left[\mathrm{CO}_{2}\right]$, warming, and soil moisture. Journal of Plant Ecology, 2(1): 1-11.

Epstein H E, Lauenroth W K, Burke I C. 1997. Effects of temperature and soil texture on ANPP in the U.S. Great Plains. Ecology, 78(8): 2628-2631.

FAO. 1992. Report on the round table on pastoralism. FAO Technical Cooperation Programme, Project TCP/IRA/2255. Rome: FAO.

Field C B, Behrenfeld M J, Randerson J T, et al. 1998. Primary production of the biosphere: integrating terrestrial and oceanic components. Science, 281(5374): 237-240.

Francis R C, Van Dyne G M, Williams B K. 1979. An evaluation of weight estimation double sampling as a method of botanical analysis. Journal of Environmental Management, 8: 55-72.

Gang C, Zhou W, Wang Z, et al. 2015. Comparative assessment of grassland NPP dynamics in response to climate change in China, North America, Europe and Australia from 1981 to 2010. Journal of Agronomy and Crop Science, 201(1): 57-68.

Gao Y H, Zhou X, Wang Q, et al. 2013. Vegetation net primary productivity and its response to climate change during 2001-2008 in the Tibetan Plateau. Science of the Total Environment, 444: 356-362.

George M R, Williams W A, McDougald N K, et al. 1989. Predicting peak standing crop on annual range using weather variables. Journal of Range Management, 42(6): 508-513.

González-Megías A, Menéndez R. 2012. Climate change effects on above- and below-ground interactions in a dryland ecosystem. Philosophical Transactions of the Royal Society B: Biological Sciences, 367(1606): 3115-3124.

Goraghani H R S, Sardo M S, Azizi N, et al. 2014. Investigation of changes in rangeland vegetation regarding different slopes, elevation and geographical aspects (Case Study: Yazi Rangeland, Noor County, Iran). Journal of Rangeland Science, 4(3): 246-255.

Guisan A, Zimmermann N E. 2000. Predictive habitat distribution models in ecology. Ecological Modelling, 135(2-3): 
$147-186$.

Hanafin J A, McGrath R, Semmler T, et al. 2011. Air flow and stability indices in GCM future and control runs. International Journal of Climatology, 31(8): 1240-1247.

Hannan S A, Manza R R, Ramteke R J. 2010. Generalized regression neural network and radial basis function for heart disease diagnosis. International Journal of Computer Applications, 7(13): 7-13.

Havstad K M, Peters D P C, Skaggs R, et al. 2007. Ecological services to and from rangelands of the United States. Ecological Economics, 64(2): 261-268.

Holechek J L. 1988. An approach for setting the stocking rate. Rangelands, 10(1): 10-14.

Humphrey R R. 1949. Field comments on the range condition method of forage survey. Journal of Range Management, 2(1): $1-10$.

Ingram J C, Dawson T P, Whittaker R J. 2005. Mapping tropical forest structure in southeastern Madagascar using remote sensing and artificial neural networks. Remote Sensing of Environment, 94(4): 491-507.

IPCC. 2007. Climate Change 2007: The Physical Science Basis. Contribution of Working Group I to the Fourth Assessment Report of the Intergovernmental Panel on Climate Change. Cambridge: Cambridge University Press, 989.

IPCC. 2013. Annex III: Glossary. In: Stocker T F, Qin D, Plattner G K, et al. Climate Change 2013: The Physical Science Basis. Contribution of Working Group I to the Fifth Assessment Report of the Intergovernmental Panel on Climate Change. Cambridge, United Kingdom, New York, NY, USA: Cambridge University Press, 1447-1466.

Kawada K, Suzuki K, Suganuma H, et al. 2012. Plant biodiversity in the semi-arid zone of Tunisia. Journal of Arid Land Studies, 22(1): 83-86.

Khanum R, Mumtaz A S, Kumar S. 2013. Predicting impacts of climate change on medicinal asclepiads of Pakistan using Maxent modeling. Acta Oecologica, 49: 23-31.

Knapp A K, Smith M D. 2001. Variation among biomes in temporal dynamics of aboveground primary production. Science, 291(5503): 481-484.

Köchy M, Mathaj M, Jeltsch F, et al. 2008. Resilience of stocking capacity to changing climate in arid to Mediterranean landscapes. Regional Environmental Change, 8(2): 73-87.

Krinner G, Viovy N, de Noblet-Ducoudré N, et al. 2005. A dynamic global vegetation model for studies of the coupled atmosphere-biosphere system. Global Biogeochemical Cycles, 19(1): GB1015.

Lauenroth W K, Sala O E. 1992. Long-term forage production of North American shortgrass steppe. Ecological Applications, 2(4): 397-403.

Lee S, Park I, Koo B J, et al. 2013. Macrobenthos habitat potential mapping using GIS-based artificial neural network models. Marine Pollution Bulletin, 67(1-2): 177-186.

Lek S, Guégan J F. 1999. Artificial neural networks as a tool in ecological modelling, an introduction. Ecological Modelling, 120(2-3): 65-73.

Liang E Y, Shao X M, Kong Z C, et al. 2003. The extreme drought in the 1920s and its effect on tree growth deduced from tree ring analysis: A case study in north China. Annals of Forest Science, 60(2): 145-152.

Linderman M, Liu J, Qi J, et al. 2004. Using artificial neural networks to map the spatial distribution of understorey bamboo from remote sensing data. International Journal of Remote Sensing, 25(9): 1685-1700.

Luo T X, Li W H, Zhu H Z. 2002. Estimated biomass and productivity of natural vegetation on the Tibetan Plateau. Ecological Applications, 12(4): 980-997.

Melillo J M, Mcguire A D, Kicklighter D W, et al. 1993. Global climate change and terrestrial net primary production. Nature, 363(6426): 234-240.

Miehe S, Kluge J, Von Wehrden H, et al. 2010. Long-term degradation of Sahelian rangeland detected by 27 years of field study in Senegal. Journal of Applied Ecology, 47(3): 692-700.

Mowll W, Blumenthal D M, Cherwin K, et al. 2015. Climatic controls of aboveground net primary production in semi-arid grasslands along a latitudinal gradient portend low sensitivity to warming. Oecologia, 177(4): 959-969.

Munasinghe M. 2009. Sustainable Development in Practice: Sustainomics Methodology and Applications. Cambridge: Cambridge University Press, 652.

Nemani R R, Keeling C D, Hashimoto H, et al. 2003. Climate-driven increases in global terrestrial net primary production from 1982 to 1999 . Science, 300(5625): 1560-1563.

O'Mara F P. 2012. The role of grasslands in food security and climate change. Annals of Botany, 110(6): 1263-1270.

Olden J D, Lawler J J, Poff N L. 2008. Machine learning methods without tears: a primer for ecologists. The Quarterly Review of Biology, 83(2): 171-193.

Prudhomme C, Wilby R L, Crooks S, et al. 2010. Scenario-neutral approach to climate change impact studies: application to 
flood risk. Journal of Hydrology, 390(3-4): 198-209.

Rathore A, Jasrai Y T. 2013. Growth and chlorophyll levels of selected plants with varying photosynthetic pathways $\left(\mathrm{C}_{3}, \mathrm{C}_{4}\right.$ and CAM). International Journal of Scientific \& Engineering Research, 4(2): 1-4.

Ray R, Gururaja K V, Ramchandra T V. 2011. Predictive distribution modeling for rare Himalayan medicinal plant Berberis aristata DC. Journal of Environmental Biology, 32(6): 725-730.

Reynolds J F, Smith D M S, Lambin E F, et al. 2007. Global desertification: Building a science for dry land development. Science, 316(5826): 847-851.

Rummukainen M. 2012. Changes in climate and weather extremes in the $21^{\text {st }}$ century. Climate Change, 3(2): $115-129$.

Schuur E A, Matson P A. 2001. Net primary productivity and nutrient cycling across a mesic to wet precipitation gradient in Hawaiian montane forest. Oecologia, 128(3): 431-442.

Scurlock J M O, Johnson K, Olson R J. 2002. Estimating net primary productivity from grassland biomass dynamics measurements. Global Change Biology, 8(8): 736-753.

Shaw M R, Pendleton L, Cameron D R, et al. 2011. The impact of climate change on California's ecosystem services. Climatic Change, 109(Suppl.): 465-484.

Sitch S, Smith B, Prentice I C, et al. 2003. Evaluation of ecosystem dynamics, plant geography and terrestrial carbon cycling in the LPJ dynamic global vegetation model. Global Change Biology, 9(2): 161-185.

Smith M D, La Pierre K J, Collins S L, et al. 2015. Global environmental change and the nature of aboveground net primary productivity responses: insights from long-term experiments. Oecologia, 177(4): 935-947.

Smoliak S. 1956. Influence of climatic conditions on forage production of shortgrass rangeland. Journal of Range Management, 9(2): 89-91.

Steffen W L, Walker B H, Ingram J S, et al. 1992. Global change and terrestrial ecosystems: The operational plan. Global Change Report 21. Stockholm, Sweden: IGBP, 95.

Tanaka K, Taino S, Haraguchi H, et al. 2012. Warming off southwestern Japan linked to distributional shifts of subtidal canopy-forming seaweeds. Ecology and Evolution, 2(11): 2854-2865.

Torell L A, Lyon K S, Godfrey E B. 1990. Long-run versus short-run planning horizons and the rangeland stocking rate decision. American Journal of Agricultural Economics, 73(3): 795-807.

Wilds S, Boetsch J R, van Manen F T, et al. 2000. Modeling the distributions of species and communities in Great Smoky Mountains National Park. Computers and Electronics in Agriculture, 27(1-3): 389-392.

Wilm H G, Costello D F, Klipple G E. 1944. Estimating forage yield by the double-sampling method. Journal of the American Society of Agronomy, 36(3): 194-203.

Wu X Y, Zhang X F, Dong S K, et al. 2015. Local perceptions of rangeland degradation and climate change in the pastoral society of Qinghai-Tibetan Plateau. The Rangeland Journal, 37(1): 11-19.

Zar J H. 2010. Biostatistical Analysis (5 $5^{\text {th }}$ ed.). New Jersey: Pearson Prentice Hall, 944. 